\title{
Imigração Polonesa no Rio Grande do Sul e a I Guerra Mundial: as divisões na colônia polonesa através do relatório "A Missão Polaca"
}

\section{Polish Immigration in Rio Grande do Sul and World War I: divisions in the Polish colony through the report "The Polish Mission"}

\author{
Rhuan Targino Zaleski Trindade* \\ Adriano Malikoski*
}

\begin{abstract}
Resumo
O objetivo deste artigo é analisar como a formação de uma Polonidade ou o devotamento étnico pela nacionalidade polonesa e seus conflitos étnicosidentitários foram importantes para o engajamento da imigração polonesa no Rio Grande do Sul em prol da independência da Polônia, no cenário da Primeira Guerra Mundial. Teoricamente buscamos nos preceitos de autores como Bourdieu (1989), Hobsbawm (2008) e Barth (1998) analisar diferentes documentos dando ênfase especial ao relatório da "Missão Polaca" produzido por Miguel Chmielewski, enquanto juiz distrital da sede do município de São Leopoldo-RS em 30 de março de 1918, ao então governador do estado, Borges de Medeiros. Existiam múltiplas vinculações entre os poloneses emigrados, durante a emergência do conflito mundial em referência à possibilidade de retorno da independência polonesa após mais de um século de dominação estrangeira. Ademais por ser um relatório para o presidente do Estado, buscouse demonstrar o engajamento dos imigrantes com os aliados, então apoiados oficialmente pelo Brasil.
\end{abstract}

Palavras-chave: Primeira Guerra Mundial; Missão Polaca; Imigração Polonesa

\section{Abstract}

The aim of this article is to analyze how the formation of a Polishness or the ethnic devotion by the Polish nationality and its ethnic-identitarian conflicts were important for the engagement of the Polish immigration in Rio Grande do Sul in favor of the independence of Poland in the scene of the First War World. Theoretically we look at the precepts of authors such as Bourdieu (1989), Hobsbawm (2008) and Barth (1998) to analyze different documents with

\footnotetext{
*Mestre em História pela UFRGS. Professor Colaborador na UNICENTRO, campus de Irati. E-mail: rhuan. trindade@hotmail.com.
}

${ }^{*}$ Mestre em Educação pela UCS. Professor na UCS. E-mail: amalikoski@ucs.br. 
special emphasis on the report of the "Polish Mission" produced by Miguel Chmielewski as district judge of the county seat of São Leopoldo-RS on March 30, 1918, to the then governor of the state, Borges de Medeiros. There were multiple links between emigrated Poles during the emergence of world conflict in reference to the possibility of return of Polish independence after more than a century of foreign domination. Besides being a report for the president of the State, it tried to demonstrate the engagement of the immigrants with the allies, then officially supported by Brazil.

Key-words: First World War; Polish Mission; Polish Immigration

\section{Considerações iniciais}

O processo de construção da identidade polonesa no Rio Grande do Sul integra um movimento amplo de formação de sentidos étnico-identitários. A escrita da História possui uma função de produção de significados contextuais, em que as fontes recobram representações ordenadas do passado. Por meio de um processo epistemológico dos estudos étnicos e migratórios, analisamos diferentes documentos, que envolveram a constituição da polonidade no solo gaúcho e o desenrolar da I Guerra Mundial na Europa.

Nesse sentido, as fontes privilegiadas são os relatórios dos comitês de Guerra no Brasil produzidos por diferentes instituições étnicas polonesas, em especial o relatório da "Missão Polaca" produzido por Miguel Chmielewski, ${ }^{1}$ na época, juiz distrital da sede do município de São Leopoldo em 30 de março de 1918, ao então presidente do estado do Rio Grande do Sul, Borges de Medeiros.

Com base nesta fonte, buscamos compreender as vinculações entre os poloneses no Brasil, sobretudo no Rio Grande do Sul, e os acontecimentos da Primeira Guerra Mundial, focalizando a "ação étnica" perpetrada pelas lideranças polonesas no país com o fito de apoiar as reivindicações em prol de uma Polônia independente na Europa. Objetivamos responder como a constituição de uma polonidade foi importante para estabelecer vínculos de

\footnotetext{
${ }^{1}$ A Missão Polaca ou o Tenente Henrique Abczynski e o Jornalista Casimiro Warchalowski no Rio Grande do Sul - Relatório Apresentado ao Exmo. Sr. Dr. A, A. Borges de Medeiros Pelo Dr. Miguel Chmielewski Juiz Distrital da Sede do Município de São Leopoldo, em 30 de março de 1918. Porto Alegre Officinas graphicas d'A Federação. 1918. UFRGS/NPH - Acervo Gardolinski - Porto Alegre, RS. Miguel Chmielewski (1877-?) era advogado e servidor público do estado, além de professor nas escolas étnicas polonesas. Teve intensa atuação como liderança étnica entre os imigrantes poloneses.
} 
ação em pró da idealização de uma Polônia, nos diferentes grupos ideológicos, como o clero e os conjuntos progressistas de intelectuais.

Além disso, buscamos também demonstrar os conflitos gerados diante dos apoiadores dos distintos lados da luta pela independência da Polônia, em especial, àqueles que envolviam os vinculados aos impérios centrais representados pelas "Legiões Polonesas" de Piłsudski, ${ }^{2}$ na Galícia austro-húngara, e os "germanófilos", ambos vertentes opostas aos aliados compostos do "exército polonês" organizado pelo general Haller na França e os grupos favoráveis ao apoio da Rússia.

\section{Os poloneses no Brasil e a Primeira Guerra Mundial}

Em 1795, a Polônia foi dividida, pela terceira e definitiva vez desde 1772, entre o Império Russo, o Império Austríaco (depois Austro-Húngaro) e o Império Prussiano (depois Alemão). Essa divisão e, consequente supressão da liberdade, acarretou em diversas resistências da população polonesa ${ }^{3}$ ao longo do século XIX até o início da Primeira Guerra Mundial, quando a volta da independência se tornava uma possibilidade real.

A imigração polonesa é iniciada no Brasil em 1869, ocupando diversas regiões no sul do país. Os principais núcleos formados foram, sobretudo, no sudeste paranaense e no entorno de Curitiba, no Paraná. No Rio Grande do Sul, na serra e depois no noroeste gaúcho, concentrando-se também em regiões urbanas, como Rio Grande e Porto Alegre, onde no Quarto Distrito se formou um considerável núcleo imigratório. Em Santa Catarina, os núcleos concentraram-se no norte do Estado (outras regiões e estados também tiveram importante, ainda que menor, presença de poloneses).

No Rio Grande do Sul, as primeiras levas chegaram em 1875 e especialmente no período de 1890-1894, quando ocorre a chamada "febre brasileira". Até 1914, houve um fluxo contínuo de poloneses ao Brasil, chegando às dezenas de milhares de pessoas. Estes eram provenientes das diferentes zonas partilhadas e marcados por diferenças culturais, de períodos de chegada, de escala e função social. Mesmo assim, constituíram um "grupo étnico", moldado ao longo do tempo na interação social, o qual buscou, de diferentes formas, trabalhar em prol da independência polonesa.

\footnotetext{
${ }^{2}$ As Legiões polacas foram criadas logo da eclosão do conflito, atuando ao lado do Império Austro-Húngaro contra a Rússia.
}

${ }^{3}$ Revoltas em 1830, 1863 e 1905, em especial, na partilha russa. 
A aproximação da deflagração da I Guerra Mundial, na primeira década do século XX, e o contexto anterior de mobilizações independentistas polonesas ao longo do século XIX, provocaram entre os membros da diáspora, sobretudo na intelectualidade imigrada e lideranças locais, atividades voltadas para recuperação da independência do país.

Conforme Mazurek, ${ }^{4}$

Após a eclosão do conflito europeu, envolveram-se nas questões da independência da Polônia também indivíduos do ambiente polônico. Tenho em mente aqui um pequeno grupo de intelectuais e de operários civicamente conscientizados. Da mesma forma que a sociedade polonesa no país de origem, eles estavam divididos nas chamadas orientações.

O historiador aponta para divisões internas na "comunidade" polonesa no Brasil, a quem se refere "ambiente polônico", tal e qual na Europa, entre os poderes centrais (Tríplice Aliança) e os aliados (Tríplice Entente). No país de acolhida dos imigrantes estavam, ao lado dos partidários dos poderes centrais, as pessoas ligadas com o Dr. Simão Kossobudzki. ${ }^{5}$ Estas formavam um grupo de convicções "esquerdistas, que propagavam posturas laicas e anticlericais". ${ }^{6}$ A partir de 1912, esse grupo publicou o semanário Niwa (Seara), e posteriormente o Ogniwo (Elo), ambos veículos de divulgação de suas posturas e conceitos políticos.

Em 2 de março de 1913 foi criado em Curitiba o Comitê de Defesa Nacional (Komitet Obrony Narodowej $\left.{ }^{-} \mathrm{KON}\right)$. A partir do início da Primeira Guerra Mundial, esta instituição se posicionou ao lado dos poderes centrais, sobretudo do Império Austro-Húngaro. Em 5 de outubro de 1914, aquela entidade se vinculou ao Comitê Nacional Central, em Cracóvia (então parte austríaca da Polônia Partilhada). O apoio era para as chamadas "Legiões" de Józef Piłsudski, ${ }^{7}$ inclusive com busca de voluntários na diáspora. Essa corrente era também apoiada pelo mais antigo jornal polonês publicado no Brasil, o Gazeta

\footnotetext{
${ }^{4}$ MAZUREK, Jerzy. O Brasil e a Independência da Polônia em 1918. Revista del Cesla, n. 20, 2017, p. 153.

${ }^{5}$ Médico, jornalista e professor universitário da escola de medicina da Universidade do Paraná. Teve intensa atuação à frente de sociedade e associações étnicas polonesas, com mobilização junto à maçonaria, dentre atividades políticas ligadas à setores progressistas. Teve atuação ativa nos comitês de Guerra pró-independência da Polônia e ajuda aos atingidos pelo conflito mundial nos territórios étnicos poloneses na Europa. Ligado à ala anticlerical. Desde 1913 até o fim de sua vida foi diretor da Santa Casa de Misericórdia de Curitiba. Ver WACHOWICZ, R. C. E MALCZEWSKI Z. Perfis polônicos no Brasil. Curitiba: Gráfica Vicentina, 2000.

${ }^{6}$ MAZUREK, Jerzy. O Brasil e a Independência da Polônia em 1918. Revista del Cesla, n. 20, 2017, p. 153.

${ }^{7}$ Marechal, estadista e político polonês que lutou pela independência da Polônia, sendo inclusive proclamado chefe de estado da Polônia após o término da Primeira Guerra Mundial entre 1918 e 1922. Após um golpe de estado retorna ao poder em 1926. Ver NOWIŃSKI, D. Józef Piłsudski, „Komendant, Naczelnik, Marszałek. Józef Piłsudski i jego czasy". Varsóvia: Wywiał, 2015
} 
Polska w Brazylii (Gazeta Polonesa no Brasil), então sob organização dos padres verbistas, ${ }^{8}$ conhecidos por serem "germanófilos".

Em apoio aos impérios centrais, foram criadas, ainda, a Comissão Militar Polonesa, em Ponta Grossa, em 07 de abril de 1913; e a Liga Polonesa, em Porto Alegre, de junho de 1916 (com ligações ao Comitê de Defesa Nacional de (hicago), dentro de uma conjuntura específica de neutralidade do Brasil e mobilizações em torno da figura de Piłsudski.

Juntaram-se, ainda, ao grupo pró-Impérios centrais, algumas sociedades de Curitiba e do interior, por exemplo, a publicação quinzenal Kolonista Polski (O colono polonês), editada pelo Pe. Antoni Cuber em Ijuí, o Tygodnik Związkowy (Semanário da União), editado pelo professor Franciszek Hanas ${ }^{10}$ em Guarani das Missões, a publicação satírica, publicada em Curitiba, por Witold Żongołłowicz, ${ }^{11}$ Człowiek Leśny (O homem do mato), todas veiculadoras de apoio à Aliança, pelo menos até 1917.

Entre os intelectuais apoiadores daquele lado do conflito estavam o professor da Sociedade das Escolas Populares, Konrad Jeziorowski, ${ }^{12}$ bem

\footnotetext{
${ }^{8}$ Os Missionários do Verbo Divino ou Verbitas, eram uma congregação religiosa católica fundada em Steyl, nos Países Baixos, em 1875, pelo padre alemão Arnaldo Janssen. De acordo com Malczewski (sd) os verbistas vieram ao Brasil em 1895 e iniciaram sua atuação junto aos imigrantes poloneses na paróquia de S. José dos Pinhais, no Paraná, em 1900. Desde então, atuaram em diferentes núcleos coloniais poloneses no Paraná e no Rio Grande do Sul. Muitos eram considerados alemães ou vistos como tendo a língua alemã como de uso comum, falando muito mal o polonês, portanto, eram frequentemente apontados como "germanófilos".

${ }^{9}$ WACHOWICZ, Ruy C. O camponês polonês no Brasil. Curitiba: Casa Romário Martins, 1981.

${ }^{10}$ Franciszek Hanas, (1889-1939), foi professor e autor de livros didáticos para as escolas étnicas polonesas no Brasil. Foi um dos fundadores da Associação dos Professores Poloneses no Paraná em 1913. Esteve à frente de escolas e demais instituições étnicas em Guarani das Missões no Rio Grande do Sul. Ver Wachowicz e Malczewski, op. cit..

${ }^{11}$ Witold Żongołłowicz (1879 - 1928): importante ativista pela independência da Polônia imigrado ao Brasil em 1915, por motivos de atuação em processos revolucionários na Polônia. Ver Wachowicz e Malczewski, op. cit.

${ }^{12}$ Konrad Jeziorowski (1876 - 1876): professor e escritor, autor de livros didáticos para as escolas da imigração polonesa. Teve constante atuação política e revolucionária na Polônia contra a ocupação russa, sendo partidário de Józef Pilsudski. Imigrado ao Brasil em 1908, atuou como professor e redator do jornal Swit, de orientação progressista. Ver Wachowicz e Malczewski, op. cit.
} 
como Michał Sekuła, ${ }^{13}$ Józef Czaki ${ }^{14}$ e Juliusz Szymański. ${ }^{15}$ Esse agrupamento instituiu, em 1916, a União das Organizações Polonesas pela Independência, tendo Kossobudzki como seu presidente. O semanário Ogniwo (O Elo), que em 1916 se transformou em Pobudka (Toque de Alvorada) e a seguir - a partir de meados de 1918 - começou a ser publicado como Świt (Alvorecer), era a principal publicação de divulgação deste grupo, pejorativamente chamados de "germanófilos".

\section{Segundo o relatório de Chmielewski ${ }^{16}$}

Quando os jornaes em Novembro de 1916 noticiaram a libertação, que o kaiser proclamara, da Polonia, a sociedade denominada «Liga Polaca» de Porto Alegre, entendeu que devia ir, como de facto foi representada por alguns de seus sócios, agradecer e prestar por isso as suas homenagens ao cônsul da Alemanha aqui como ao representante do imperador Guilherme. Bem entendido, tais pessoas fizeram isso em nome da referida sociedade - e tão somente. O jornal «Diário» que se publicava aqui nesse tempo, e que apesar de editado em português, era, sabia-se, um jornal alemão, noticiou imediatamente que tais homenagens foram exprimidas pela Polônia Porto-Alegrense, isto é, por toda ela.

Como era de esperar, essa noticia desagradou profundamente a colônia polaca de Porto Alegre, inclusive todas as suas três, outras, sociedades. Já antes disso não se solidarizavam os polacos nem simpatizavam com tal Liga, formada apenas de alguns sócios - grande admiradora nesta guerra dos impérios centrais, principalmente da Áustria, - quanto mais ainda agora em virtude dessa conduta, a qual não nobilitava de maneira alguma a colônia local polaca. ${ }^{17}$

O autor, no texto em 1918, já com o Brasil ao lado da Entente, pretendia, primeiramente, deslegitimar aquela aproximação inicial dos poloneses da capital gaúcha com os Impérios centrais, quando havia sido criado o Reino

\footnotetext{
${ }^{13}$ Michał Sekuła (1884-?): antes de emigrar para o Brasil, era filiado ao Partido Socialista Polonês e por sua participação em movimentos clandestinos pela independência da Polônia, foi perseguido após a Revolução de 1905 contra a Rússia. Após curto período de estada nos Estados Unidos reemigrou para o Brasil em 1908, estando à frente de organização das escolas polonesas. Retornou para a Polônia após a independência, concluindo o curso de magistério. Ver Wachowicz e Malczewski, op. cit.

${ }^{14}$ Józef Czaki (1857-1946): foi zoólogo, geólogo, militar e médico. Como coronel do exército imperial russo foi acusado de conspiração e fugiu da Rússia para os Estados Unidos. Posteriormente reemigrou para o Brasil no estado do Paraná. Teve atuação importante com médico na região de Araucária. Coletou diferentes espécimes da fauna brasileira e enviou para a Polônia. Tinha orientação socialista, oposto à ideias religiosas e conservadoras. No entanto, defendia o nacionalismo e o fortalecimento da polonidade para com a imigração polonesa. Ver Wachowicz e Malczewski, op. cit.

${ }^{15}$ Juliusz Szymański (1870-1958): médico, escritor e ativista cultural pela aproximação do Brasil e a Polônia. Após participação em atividades da resistência contra o império russo, enquanto servia na guerra da Rússia contra o Japão, teve que fugir para os Estados Unidos para não ser preso. Em 1912 reemigra para o Brasil, sendo professor na área de oftalmologia na Universidade do Paraná. Ver Wachowicz e Malczewski, op. cit.

${ }^{16}$ Atualizamos o vernáculo para o acordo gramatical corrente.

${ }^{17}$ CHMIELEWSKI, op. cit., p. 9-10.
} 
Regencial da Polônia, em novembro de 1916, pela Alemanha e a ÁustriaHungria, no antigo território polonês conhecido como Congresso da Polônia, parte do domínio russo.

Em segundo lugar, o autor criava uma identidade comum, com as referidas denominações: "Polônia porto-alegrense" (o primeiro vocábulo representando a comunidade da diáspora), ou a "colônia polaca", para os poloneses de uma determinada região do Brasil, como um grupo específico. Ainda que manifestasse a divisão interna dele, procurava nominá-lo de maneira ampla e apenas separando possíveis elementos dissonantes, ou seja, criava um "nós" polonês diante dos "outros", fossem os alemães, fossem os elementos que se desviavam de uma ação conjunta.

Em resposta ao agradecimento feito ao consulado alemão, em fins de 1916, segundo o autor da "Missão Polaca", foi convocado um "comício geral", na sede da sociedade Águia Branca de Porto Alegre e reunidos ali membros da "Polônia porto-alegrense": "protestaram fervorosamente contra quaisquer agradecimentos à Alemanha e contra a nutrição de qualquer simpatia da parte dos polacos para com a mesma" e "fizeram ver que não lhes merece fé alguma a promessa do kaiser prussiano por conhecerem de sobra os instintos bárbaros dos sucessório dos Cavalheiros da Cruz". ${ }^{18}$

A marca do discurso de Chmielewski em seu relatório é o objetivo de profundo descolamento da "comunidade" polonesa no Rio Grande do Sul com relação aos, então, a partir de 1917, inimigos do Brasil, a Aliança e seus impérios integrantes, bem como conformar os poloneses em contraste aos alemães, considerados inimigos "bárbaros", indignos de confiança, pelos quais não havia simpatia da "Polônia porto-alegrense".

Em oposição ao grupo anterior estava aquele centrado na figura de Casimiro Warchałowski, ${ }^{19}$ por meio do jornal que editava em Curitiba, desde 1904, o Polak w Brazylii (O polonês no Brasil). Conforme Mazurek,

Essa facção consolidou-se definitivamente nos primeiros meses de 1915. Seus membros eram partidários da cooperação com a Rússia, e também com os seus aliados: a França e a Inglaterra. Eles acreditavam que a cooperação com a Rússia contribuiria para a união de todas as terras polonesas e, em consequência, para a independência da Polônia. ${ }^{20}$

\footnotetext{
${ }^{18}$ Ibidem.

${ }^{19}$ Casimiro Warchałowski (1872-1943) foi jornalista, comerciante e diplomata pela Polônia, além de ativista cultural entre a imigração polonesa no Brasil, liderando núcleos de colonização polonesa no Paraná e no Peru. Ligado à maçonaria era considerado um líder anticlerical.
}

${ }^{20}$ MAZUREK op. cit. p. 
A mudança da conjuntura mundial, em especial a partir de abril de 1917, quando o Brasil toma posição em apoio aos aliados, rompendo relações diplomáticas com a Alemanha, foi um fator determinante para a proeminência deste segundo grupamento, sob a liderança de Warchałowski.

Um "exército polonês" (como ficaria conhecido), sob o comando do general Haller, ${ }^{21}$ começa a ser montado na França, por meio do decreto presidencial de Raymond Poincaré no dia 4 de junho de 1917, que mobilizou a comunidade polonesa no Brasil. Alguns dias depois, com liderança de Edward Płużański, juntamente com Jakub Kosinski, foi elaborado o estatuto do Comitê Nacional Polonês, aprovado no dia 8 de julho de 1917, durante um comício da coletividade polonesa no Rio de Janeiro.

Fruto dessa mobilização em prol dos aliados, temos a visita da missão do tenente polonês Henrique Abczyński ao Brasil e ao Rio Grande de Sul, com objetivos específicos de angariar apoio à causa e voluntários para compor o grupo militar. A passagem da "Missão Polaca" é marcada igualmente por um forte posicionamento antigermânico e contra os Impérios Centrais, demonstrado em seus discursos e práticas ao longo da visitação dos núcleos poloneses pelo Rio Grande do Sul.

Segundo Chmielewski, em seu discurso da Sociedade Águia Branca em Porto Alegre, Borges de Medeiros mandou um recado aos poloneses, no qual afirmava a liberdade próxima da Polônia, que, contudo, não iria advir da Alemanha, mas sim, dos aliados. Os discursos reproduzidos pelo autor de suas reuniões marcam este tom, com passagens da história polonesa e seus conflitos com os alemães (ainda que os maiores tenham sido com a Rússia, este elemento parece obscurecido diante do contexto da época). Abczyński ressaltava, em suas falas, a luta da civilização (dos Aliados) contra a barbárie (dos poderes centrais e da Alemanha), sendo a vitória da primeira que libertaria a Polônia, com o esforço, mais que apenas de "legiões", mas do "exército polaco":

as forças militares polacas organizadas na França, não apenas com o nome de legiões, mas de exercito polaco, são o símbolo vivo dessa independência reconhecida e amparada pelas potências referidas.

E ele, o tenente Abczynski, mensageiro desse exército, fazia aqui apelo aos que podem tomar parte nas fileiras desses guerreiros, para com ele irem com as armas na mão levantar bem alto o glorioso estandarte da liberdade.

\footnotetext{
${ }^{21}$ Józef Haller von Hallenburg era general do exército formado na França por voluntários poloneses que serviram às forças aliadas na Primeira Guerra Mundial. Este agrupamento representava as legiões polonesas organizadas na Europa Ocidental que tinha como objetivo lutar pela independência da Polônia na Europa.
} 
Contudo - acrescentou - aqueles que por vários motivos superiores não nos poderem acompanhar, aqueles que aqui ficarem, ele, apesar de não vestirem a farda militarem, que se considerem, entretanto, soldados na luta ativa contra o bárbaro militarismo prussiano. ${ }^{22}$

O autor eximia, em alguma medida, também as Legiões de Pilsudski de sua luta inicial contra a Rússia, como sendo igualmente vitimada pelos "prussianos", estes seus maiores inimigos. De fato, não se tratava apenas de uma missão para angariar voluntários ou apoio material, mas também uma propaganda para o esforço de guerra do Exército de Haller na França e para unir os poloneses, diante das divisões internas grupais, condenando o apoio à Alemanha e aproveitando o momento de hostilidade brasileira para com aquele país.

\section{Conflitos de identidades}

No século XIX e início do século XX, durante a ocupação estrangeira, se configura o nacionalismo polonês, ou a chamada polonidade num contexto da emergência dos nacionalismos europeus, o que Hobsbawm ${ }^{23}$ considera como nacionalismo político: baseado na língua, na etnia e na autonomia estatal, vinculados à direita política. Contudo, devemos lembrar da especificidade do caso polonês, isto é, a falta de um Estado capaz de promover o nacionalismo, diferente do que ocorria em outros países.

Hobsbawm examina que o nacionalismo polonês tinha sua emergência na luta pela recuperação do Estado, fundamentado numa comunidade mais religiosa que linguística, lastreado por um trabalho de formulação feito por intelectuais poloneses nacionalistas engajados na luta independentista. Portanto, o que existiria seria um protonacionalismo com o objetivo de lutar contra o(s) invasor(es) e recuperar a independência. ${ }^{24}$

Os grupos imigrantes no Brasil, desde a saída dos locais de origem, depois com a chegada e alocação no país de acolhida, bem como a partir da estada e interação com os outros grupos imigrantes e nacionais, constituíram múltiplas identidades, sobretudo étnicas. Nesse contexto, as identidades nacionais já preexistentes poderiam ser reconstruídas, a partir de condições interacionais distintas. A fim de desenvolver estas questões, há que se

\footnotetext{
${ }^{22}$ CHMIELEWSKI, op. cit., p.18.

${ }^{23}$ HOBSBAWM, Eric. Nações e Nacionalismos desde 1780. Rio de Janeiro: Paz e Terra, 2008, p. 206.

${ }^{24}$ Ibidem.
} 
demarcar as dinâmicas impostas para a delimitação do grupo étnico e, logo, a constituição de uma "identidade étnica".

Segundo Barth ${ }^{25}$ a definição de um grupo étnico ocorre através da interação social, a qual se constitui com a geração de processos de inclusão e exclusão, consequentemente permitindo a delimitação de fronteiras. Para a configuração destas, são elencados ou transformados elementos de distinção e de diferenciação social, ${ }^{26}$ características compartilhadas, fundamentadas como símbolos identitários, as quais instituem a crença e o sentimento de pertença em uma origem comum (como a língua). Max Weber ${ }^{27}$ já definia que a crença na procedência comum era elemento fundamental para o pertencimento a uma comunidade, ao que somava ser a distinção ingrediente para o estabelecimento dos grupos e a instauração de elementos culturais, os quais alimentavam sentimentos de "honra étnica" e "dignidade", sustentáculos, na visão dele, da identidade grupal.

O fato é que a identidade étnica se baseava em um elemento contrastivo, um heterorreconhecimento e um autorreconhecimento, os quais marcavam a constituição de um "nós" e dos "outros", sobretudo através de marcadores positivos do primeiro e desabonadores para os segundos. Este processo de idealização de si mesmo, feito por um grupo, estabelecendo fronteiras, é influenciado por diversos outros âmbitos sociais, políticos e institucionais: governos do país de origem, religião, instituições étnicas, considerando aqui também as escolas, intelectuais e líderes, contribuintes para o desenvolvimento e estabelecimento do caráter identitário.

Neste ínterim, existe uma multiplicidade de configurações identitárias dentro de um grupo que se pretendia polonês: primeiramente, desde a pré-imigração (marcadores regionais), dos países ocupantes, em seus ideais de identidade nacional ou no protonacionalismo de que trata Hobsbawm..$^{28}$ De outro lado, há outras configurações demarcadas como as constituições da terra de acolhida, com o processo de identificação dos poloneses frente a outros grupos imigrantes, como alemães e italianos, e com os chamados "nacionais", indivíduos que já habitavam os territórios brasileiros, bem como nos diferentes espaços de alocação e períodos de chegada desses imigrantes.

Com base nestes pressupostos, é importante ressaltar que o trabalho de constituição da etnicidade é atravessado pelo papel central dos "líderes

\footnotetext{
${ }^{25}$ BARTH, Frederik. Grupos étnicos e suas fronteiras. São Paulo: UNESP, 1998.

${ }^{26}$ STREIFF-FENART, Jocelyne, POUTIGNAT, Philippe. Teorias da Etnicidade. São Paulo: UNESP, 1998.

${ }^{27}$ WEBER, Max. Economia e Sociedade. Brasília: Ed. UNB, 1994.

${ }^{28}$ HOBSBAWM, op. cit.
} 
étnicos", ${ }^{29}$ com propostas unificadoras. Estes entendidos como os notáveis do grupo, sejam intelectuais, padres, entre outros personagens, os quais através de "ações étnicas", como a condução e organização de instituições (sociedades recreativas e culturais, igrejas, grupos de dança, escolas, associações esportivas, periódicos etc.) mobilizam fazeres e valores culturais específicos. Dentre estes fazeres, estão prescrições culturais, promovidas pela produção de características que preservam ou definem a etnicidade polonesa, como a linguagem ou a religiosidade, dentre outros, ligados aos pressupostos de nacionalidade ou de origem migrante.

Os líderes são aqueles que consolidam a delimitação de etnicidade do grupo enquanto tal, conforme o que Bourdieu ${ }^{30}$ chama de "poder de enunciação", e, por meio deste "poder", temos a constituição do que compreendemos como um "grupo", no nosso caso, "étnico". Segundo Bourdieu ${ }^{31}$ existe quase um "ato mágico", envolvendo o poder (simbólico) de uma formulação definidora aceitável no corpo social, de modo que os "porta-vozes", as lideranças pertencentes a grupos privilegiados socialmente, tem o poder de fazer a enunciação, ou a nomeação dos valores aceitos. Os poloneses enquanto grupo possuem suas características moldadas também por esses representantes, ou agentes de identidade. ${ }^{32}$ Recebem o poder para enunciar o próprio grupo, fazendo um caminho de mão dupla: "o representante faz o grupo que o faz". O nome possui o poder unificador e produz uma diferenciação em relação aos "os outros". Ao usar termos como "colônia polaca" ou "Polônia rio-grandense" e "Polônia porto-alegrense", Chmielewski faz essas nominações unificadoras e constituidoras de uma identidade específica.

A busca por nominações aglutinantes, a separação com o elemento alemão e aproximação com os poderes aliados, o obscurecimento da rivalidade com o secular domínio russo, a reafirmação de um posicionamento de "polonidade" lastreado pela institucionalização étnica (sociedades e periódicos) voltados a um determinado posicionamento, são alguns dos "marcadores de diferenciação", que ajudam na conformação de um "nós" "poloneses”, ou seja, de um grupo étnico polonês, conforme se discute ao longo da avaliação da "Missão Polaca".

\footnotetext{
${ }^{29}$ WEBER, Regina. Líderes, intelectuais e agentes étnicos: significados e interpretações. Diálogos, v. 18, n. 2, 2014, pp. 703-733. WEBER, Regina. Agentes e intelectuais étnicos entre os poloneses. Tempos Históricos, V. 19 , n. 1, 2015, pp. 253-273.

${ }^{30}$ BOURDIEU, Pierre. O poder simbólico. Lisboa: DIFEL/Bertrand Brasil, 1989.

${ }^{31}$ Ibidem.

${ }^{32}$ GIMENEZ, Gilberto. Materiales para una nueva teoria de las identidades sociales. Revista Frontera Norte, v.9, n. 18, 1997.
} 
Ainda assim, como em todo o grupo social, existiam divisões internas. No caso polonês, a principal delas se destacava na preponderância clerical em oposição aos objetivos das lideranças laicas, por vezes, ligadas a ideais progressistas e movimentos independentistas. A querela clericais x anticlericais reverberou entre os poloneses e mobilizou diferentes aspectos sociais, como ideais distintos quanto à preponderância religiosa e diferentes instituições criadas por líderes de ambos os grupos. Os jornais, subvencionados e escritos pelas lideranças divergentes, sobretudo, expunham as disputas e conflitos internos através de seus textos críticos.

Em Curitiba, na visão do historiador vicentino ${ }^{33} \mathrm{Piton}^{34}$, o final da primeira década do século XX foi um período de "batalha pela hegemonia na colônia polonesa", aonde já existia uma atividade dos padres desde os primórdios da imigração, que são confrontadas posteriormente pela vinda de intelectuais laicos.

Nesse contexto, mesmo diante do objetivo comum de reconquista da independência polonesa, as diferentes configurações identitárias dentro da "comunidade" e os distintos grupos em conflito, baseados em múltiplas lideranças, conduziram a divisões quanto aos rumos a serem tomados e impediram uma ação mais sistemática em prol da Independência da Polônia, com mobilizações que variavam de acordo também com os lados em disputa na Europa.

\section{A Resolução Curitibana}

Uma das principais decisões referentes à participação da "comunidade" polonesa junto à mobilização na I Guerra Mundial, foi a aprovação da chamada "Resolução Curitibana". Este documento possui as bases e diretrizes para o trabalho da luta pela independência polonesa, em especial, oposta aos adeptos da perspectiva alemã. O documento foi publicado na íntegra nas páginas do relatório de Chmielewski e também no periódico Polak w Brazylii.

Conforme apontava a Resolução, o vínculo com os aliados e a vitória sobre a Alemanha eram fundamentais para o restabelecimento polonês:

\footnotetext{
${ }^{33}$ Congregação religiosa formada na França, mas que se preocupou no atendimento espiritual e também secular dos imigrantes poloneses no sul do Brasil, especialmente com a instauração em 1903 da ViceProvíncia Vicentina em Curitiba, que respondia à Cracóvia. Muitos padres vicentinos eram poloneses.

${ }^{34}$ PITON, Jan. Periódicos de Língua Polonesa no Brasil. In: Anais da Comunidade Brasileiro-Polonesa Volume III, Curitiba, 1971. pp. 80-103.
} 
A aspiração constante de toda a nação polaca é a unificação e a restauração da Polônia livre dentro de suas antigas fronteiras, compreendendo o rio Vístula em toda a sua extensão, inclusive a foz do mesmo,

A realização deste desejo nacional poderá ter lugar unicamente pela destruição do militarismo prussiano e pela extinção de sua preponderância na Europa. E em virtude de terem os países aliados, inclusive os Estados Unidos e o Brasil, incluído na base de seus fins, na presente guerra, a defesa do direito de regeremse todos os povos livremente formando Estados independentes, resulta disso que os interesses dos polacos harmonizam-se completamente com os interesses dos aliados. ${ }^{35}$

A orientação, quanto à política polonesa, seria “a mesma que está sendo evidenciada pelos polacos residentes em todas as três partes da Polônia, bem assim, que é sustentada pela grande maioria dos que residem fora dela, tanto na Europa, como na América". ${ }^{36}$ Assim, com base nestes argumentos, o referido documento estaria de acordo com a resolução do Comitê da Dieta de Cracóvia, de 28 de Maio de 1917; a Declaração do Club Polonês no Parlamento Alemão; a Deliberação do comício de poloneses em Moscou, de 6 de agosto do mesmo ano, tendo por base a oposição ao recrutamento de poloneses no território ocupado pela Alemanha; bem como "a recusa formal que as legiões polacas [...] fizeram, negando-se elas a prestar o juramento de fraternidade com o exército alemão e de obediência ao seu comando". Essas condições revelariam "amplamente a orientação da política polaca". A Resolução tinha como convicção o dever de todos os poloneses de organizar o chamado "Exército Polaco", "que é símbolo vivo da Polônia que ressuscita". ${ }^{37}$

A resolução deixava clara a participação da Polônia, através de seus representantes, junto aos países aliados, sobretudo através da presença na futura Conferência de Paz. Conforme o documento se sustentava a "amizade para com a Grande Nação Brasileira, a qual os acolheu hospitaleiramente no seu seio e agora apoia generosa e desinteressadamente as suas aspirações nacionais e políticas". ${ }^{38} \mathrm{~A}$ lealdade para o com o Brasil e a aproximação com a Polônia era base de um discurso de identidade étnica e nacional, ao mesmo tempo, diante do contexto interacional de imigração e fixação no país de acolhimento e do movimento em apoio ao retorno do país de origem.

O documento incumbia ainda um então recém-eleito Comitê Central, de diferentes questões burocráticas representativas de uma unidade específica,

\footnotetext{
${ }^{35}$ CHMIELEWSKI, op. cit., p.21.

${ }^{36}$ Ibidem.

${ }^{37}$ Ibidem.

${ }^{38}$ Ibidem, p. 22.
} 
a denominada "colônia polaca no Brasil". O comitê era uma amostra da dinâmica da mobilização polonesa pró-aliados, tendo na base organizativa, em suas lideranças, a ambição de conduzirem o "grupo polonês" no país, com os seguintes objetivos:

I de representar a defesa dos interesses polacos, onde disso se revelar a necessidade:

II de informar por intermédio de seus órgãos ou publicações avulsas a opinião publica no Brasil e fora de suas fronteiras sobre a atitude dos polacos e sobre as suas aspirações;

III de congregar os esforços dos polacos no Brasil, para serem coordenados a todos os esforços dos polacos residentes na Polônia e fora dela.

o Comício incumbe o Conselho Nacional de eleger o Comitê Central de cinco membros, que será órgão executivo do Conselho e representará os interesses da colônia polaca do Brasil perante o Governo e o Povo Brasileiro.

o Comício incumbe ainda o Conselho, e eventualmente o Comitê Central, de designar o seu representante junto ao Comitê Polaco em Paris, a fim de representar a colônia polaca do Brasil. ${ }^{39}$

O Comitê Polonês de Porto Alegre organizado pela resolução, acima referida, ficou constituído de cinco membros, sendo escolhidos e eleitos os três presidentes, das três sociedades polonesas locais (Sociedade Zgoda, Sociedade Águia Branca e Sociedade Tadeusz Kościuszko), e dois outros membros da colônia- além do sexto que seria representante do Comitê Central.

Segundo Chmielewski, Warchalowski apresentou, no comício em Porto Alegre, as razões de criação do "Comitê Central Polaco", em Curitiba e de outros nas capitais de vários Estados:

Exemplificou como - si bem que, segundo foi informado, no Estado do Rio Grande do Sul não houve casos, mas em alguns outros lugares - por ocasião em que as autoridades locais tomavam certas medidas contra os alemães, muitos polacos sofreram incômodos. porque, nascidos em terras polacas usurpadas pela Alemanha, foram considerados como súditos do kaiser.

Por isso, - continuou - esses comitês fornecerão documentos, comprobatórios da nacionalidade polaca, ás pessoas que isso solicitarem e que se acharem nas devidas condições, isto é, polacos nascidos na Polônia, seja na parte do território ocupado por força das armas, pela Alemanha, seja pela Rússia ou pela Áustria; provando tais pessoas, além disso, perante os referidos comitês, de uma maneira plena, que os seus sentimentos não se acham deturpados pelas funestas ideias dos inimigos da Polônia. ${ }^{40}$

\footnotetext{
${ }^{39}$ Polak w Brazylii, n 99 de 19 de Dezembro de 1917. p. 1-6

${ }^{40}$ Ibidem.
} 
As lideranças polonesas, portanto, através dos Comitês e Resoluções, isto é, sua base organizativa conformada após a declaração de guerra do Brasil contra a Alemanha, permitiam a reconfiguração do grupo polonês, através de uma conjunção em torno do ideal da independência polonesa, confluindo os imigrantes das três partições como uma unidade, na qual se possibilitava a comprobação de uma "nacionalidade polaca" com base em documentação a ser emitida, não importando a proveniência das regiões partilhadas. A mudança da perspectiva de antigos apoiadores dos poderes centrais, inseridos no grupo polonês através do clero e outras lideranças laicas, é visível na análise de Chmielewski ao perpassar as colônias polonesas. Esta análise permite observar que houve, ainda que aparentemente, uma conjunção de discurso em prol dos Aliados, do retorno da Polônia e apoio à política brasileira, os quais reverberaram na "missão polaca" de Abczyński.

\section{A “Missão Polaca" no Rio Grande do Sul}

O texto escrito em 1918 por Miguel Chmielewski, antigo professor da Sociedade Águia Branca, e então juiz distrital da sede do município de São Leopoldo - RS, conta com 36 páginas encaminhadas ao então presidente do estado do Rio Grande do Sul, Borges de Medeiros, sobre a visita da "missão" de poloneses para aquele estado, que acompanhou pessoalmente como enviado oficial de Borges. A missão, ocorrida em 1917, foi coordenada pelo Tenente Henrique Abczyński, vindo da Europa em nome do "exército azul" dos poloneses organizado na França pelo general Haller, juntamente com o jornalista Casimiro Warchalowski de Curitiba.

O objetivo da "missão" era percorrer as colônias polonesas com o fito de angariar patrícios voluntários para combater ao lado do "exército azul" na França. Assim, visitam diversas colônias do estado, comunicando-se com lideranças, o clero, as autoridades públicas e diretamente com os colonos em cada localidade.

O texto se divide em uma "Parte Geral", subdividida: "1. A missão do engenheiro Henrique Abczynski, tenente do exército polaco organizado na França e a orientação e a atitude da colônia polaca do Brasil na atual guerra"; "2. O clero e a imprensa polaca"; "3. A Polônia Porto-Alegrense", uma "Parte Especial": "4. O comício em Porto Alegre: as sinopse dos discursos - do autor deste relatório Miguel Chmielewski, de Henrique Abczynski e de Casimiro Warchalowski"; "5. A Resolução "Curitibana e o Comitê Polaco de Porto Alegre" e a "Parte Final": "6. Os comícios nas colônias"; "7. A atitude 
dos padres"; "8. Os colégios particulares e a nacionalização"; "9. A impressão sobre o progresso das colônias"; "10. O voluntariado polaco e os brasileiros". Após solicitação de autorização a Borges de Medeiros, a comitiva com Casimiro Warchalowski e Miguel Chmielewski percorreu as então "colônias polonesas" em Porto Alegre, Mariana Pimentel, São Feliciano, ${ }^{41}$ Ijuí e Guarani, ${ }^{42}$ onde realizaram "comícios" com falas antigermânicas, em prol dos aliados, convidando voluntários ao esforço de guerra.

Em todas [...] reuniões que foram efetuadas nos lugares referidos, expúnhamos, todos os três, e desenvolvíamos as proposições [...].

A todas elas compareceu um numero relativamente grande de colonos, apesar mesmo de mau tempo, que por coincidência, desagradavelmente nos surpreendia. Em todas as fisionomias dos assistentes, em todas as suas exclamações e palavras evidenciava-se a mais sincera solidariedade com as nossas opiniões.

Todos manifestaram inequívocos desejos pela vitória dos aliados, - vitória esta que também será a do Brasil e da Polônia. ${ }^{43}$

Miguel Chmielewski elaborou o texto na forma de um relatório sobre sua peregrinação pelos núcleos de imigração polonesa do Estado, ao mesmo tempo, era uma propaganda a favor do grupo aliado e da lealdade dos poloneses. De acordo com Chmielewski,

O tenente Henrique Abczynski veio de França ao Brasil no vapor Liger, desembarcando no Rio de Janeiro em Setembro de 1917. Sobre a sua visita às colônias polacas e, bem assim, sobre a sua missão aqui, foram desde logo publicados vários artigos e noticias pelos jornais polacos, como também por algumas revistas brasileiras e jornais do Rio. Assim é que a vinda do mesmo a Porto Alegre era esperada pelos polacos aqui residentes e era mesmo por eles desejada. Sabia-se que vinha como Delegado da Missão Militar Franco-Polaca angariar no Brasil entre os seus patrícios voluntários para o exercito polaco organizado na França. ${ }^{44}$

Ao mesmo tempo faz algumas observações sobre o clero, as escolas e a situação das comunidades polonesas. 0 importante dessa missão é que, através da visita do militar polonês, o governo brasileiro, no Rio de Janeiro, passa a reconhecer a nacionalidade polonesa, como organização política autônoma. Esta era uma característica do processo de nominação, que permitia a união

\footnotetext{
${ }^{41}$ Localizadas ao sul da capital Porto Alegre.

${ }^{42}$ No noroeste do estado.

${ }^{43}$ CHMIELEWSKI, op. cit., p. 26.

${ }^{44}$ Ibidem, p. 4.
} 
dos poloneses ao não mais serem "russos", "alemães" ou "austríacos", mas separados destes através da documentação que os definira conjuntamente como grupo.

O tenente Henrique Abczynski e o jornalista Casimiro Warchalowski - redator e editor do jornal denominado «Polak w Brazyljí» que se publica em Coritiba, em polaco, duas vezes por semana - obtiveram das altas autoridades da União Brasileira, no Rio de Janeiro, o reconhecimento oficial da nacionalidade polaca.

Em virtude disso foram organizados desde logo em S. Paulo e em Coritiba os comitês polacos, autorizados, bem como o do Rio de Janeiro, a emitir ás pessoas que solicitassem, os competentes documentos, afim de não serem considerados, para todos os efeitos, como súditos russos, austríacos ou alemães, somente pelo fato de terem as respectivas potências violentamente dominado as terras da Polônia em que essas pessoas nasceram. ${ }^{45}$

A organização dos comitês para a emissão de documentos nacionais poloneses possuía um significado da recuperação da nacionalidade após mais de 123 anos de dominação dos territórios poloneses empreendidos pelas potências vizinhas. Tais comitês tiveram a autorização de autoridades brasileiras, como o Ministro do Exterior da época, Nilo Peçanha, e, também apoio dos Ministérios e Consulados dos países aliados.

Conforme o relatório de Chmielewski, a missão sofreu alguns ataques de jornais alemães e poloneses de Curitiba, que possuíam alinhamento com as potências centrais. Dentre os jornais poloneses, é mencionado o Gazeta Polska e o Pobudka, de ideologia mais religiosa e que se apresentavam contra a missão. Contudo Miguel Chmielewski sai em defesa do Jornalista e redator do Polak w Brazylii:

O Sr. Casimiro Warchalowski, desde o começo da guerra, colocára-se com o seu jornal em excepcional evidência ao lado dos aliados; e, atacando com veemência particular, aliás justa, os alemães, mostrou-se também contra as referidas legiões polacas: tratava de demonstrar a nenhuma utilidade, mesmo o prejuízo da ação das mesmas, á causa da Polônia; chegando até em seus comentários nos artigos e em palestras a trata-los com um forte menosprezo. Com isto tendo ele desgostado a muitos, inimigos até da Alemanha, sofreu graves acusações, mesmo caluniosas, por parte sobretudo dos que piamente ainda acreditavam na justiça da casta militar da Alemanha ${ }^{46}$

Muitos poloneses lutaram contra a Rússia apoiando as "legiões" formadas na Galícia austríaca e mesmo soldados da partilha alemã no exército de Guilherme II, e passaram a acreditar que, por meio da Alemanha, haveria

\footnotetext{
${ }^{45}$ Ibidem, p. 5.

${ }^{46}$ Ibidem, p. 6.
} 
a possibilidade de que a Polônia fosse reconstituída como país autônomo, sobretudo com promessas de liberdade, em 1916. Este posicionamento era combatido pelo Jornalista Casimiro Warchalowski, devido às iniciativas imperialistas do Kaiser alemão. No entanto, para o autor do relatório

É verdade que no começo da guerra muitas dezenas de milhares de voluntários polacos, organizados em legiões na Galícia (Áustria) investiram contra os exércitos do tzar moscovita e durante certo tempo continuaram, ao lado da Áustria, a combater o terrível martirizador da Polônia.

É verdade também que muitos seus patrícios aqui exprimiam àqueles heróis a sua admiração. Mas isso não queria dizer que de qualquer maneira se colocassem ao lado da Alemanha. Pelo contrario, eles diziam: «Desejamos de toda a nossa alma, a destruição completa do poder militar da Rússia « e também igualmente da Prússia.» De facto, a Rússia dos tzares era também inimiga da civilização. ${ }^{47}$

Havia a necessidade de justificação da divisão interna polonesa durante a guerra. As revoltas ao longo do XIX haviam sido direcionadas fortemente contra o Império Russo, que tinha a maior fatia dos territórios étnicos do que seria a Polônia, e mobilizaram violentos conflitos, ao contrário da parte austríaca, com maiores liberdades ${ }^{48}$, e da parte alemã, que com maior pressão, impedia levantes ${ }^{49}$. Os ataques ao Império Russo, então no lado aliado, e depois afastado do conflito pela Revolução, em especial, deveriam ser, portanto, explicados, ainda mais diante da opção brasileira no conflito em apoiar a Entente, sem prejudicar os poloneses no país.

Em relação ao clero, Miguel Chmielewski faz fortes manifestações contrárias, acusando-os de apoiarem os regimes centrais na Europa.

O clero nas colônias polacas, tanto no Paraná, como no Rio Grande do Sul, quase que na sua totalidade colocava-se com suas simpatias ao lado dos impérios centrais. Os respectivos padres, em grande maioria, falando mal o polaco e muito bem o alemão, estão sendo acusados de serem propriamente alemães, que aprenderam talvez já tardiamente na Alemanha a língua polaca com o plano certo de serem destinados para determinadas colônias neste país. ${ }^{50}$

Estes conflitos expunham as desavenças entre clericais e anticlericais' as quais desde o século XIX permeavam a colonização polonesa e se fundiram

\footnotetext{
${ }^{47}$ Ibidem, p. 5.

${ }^{48}$ WEBER, Regina, TRINDADE Rhuan Targino Zaleski. Imigrantes poloneses no Brasil no contexto da dominação austríaca. Revista del CESLA, n. 19, 2016, pp. 269-289.

${ }^{49}$ MAZUREK, Jerzy. A Polônia e seus emigrados na América Latina (até 1939). Goiânia: Espaço Acadêmico, 2016.

${ }^{50}$ CHMIELEWSKI, op. cit., p. 7
} 
às disputas entre os pró-impérios centrais e pró-aliados. Para Chmielewski, os padres

vinham [...] vindo para cá, já desde muitos anos, formando na propaganda da civilização um campo oposto àquele que ocupavam os semeadores das ideias liberais, republicanas, democráticas. Entre estes o jornalista Warchalowski, logo no começo de sua vinda para o Brasil, pregou, abertamente uma guerra pertinaz a esse clero e mesmo ao outro em geral.51

Alertava, o autor, para o esforço de Warchalowski no combate ao clero polonês, em especial, em Curitiba através de seu periódico, o qual, por sua vez, seria atacado nos púlpitos e pelo concorrente Gazeta Polska.

Diminuiu por alguns anos a luta mais pronunciada desses jornaes, mas recomeçou de novo em outro sentido, já não religioso o sim político, com a guerra. O jornal clerical manifestava sempre o seu apoio aos impérios centrais e particularmente á Alemanha, o outro, como já foi dito, aos aliados.

O jornal dos padres não só parecia ser, mas até pode-se afirmar que era um jornal alemão; o outro era acusado de servir a Rússia, si bem que, temos absoluta certeza, serve ele sempre e eficazmente, nesta guerra os interesses dos aliados em geral e sobretudo particularmente, sob o seu ponto de vista, os interesses da Polônia. ${ }^{52}$

O confronto na imprensa representava as disputas ideológicas que fomentavam a luta pela volta da independência polonesa, os diferentes lados do conflito (pró-aliados, pró-poderes centrais, pró-Rússia, pró-legiões da Galícia austríaca e pró-Alemanha) e as manifestações em favor do clero e/ou dos laicos, reverberavam nas páginas dos jornais polono-brasileiros, em especial, no Paraná e sua capital, então com maior número de poloneses e, notadamente, de intelectuais deste grupo étnico.

Chmielewski deixa claro, por exemplo, que o Pobudka" "ao romper a guerra abraçou desde logo apaixonadamente a causa da propaganda das referidas legiões e se mostrava sempre mais favorável á Áustria do que á Alemanha", de forma que "não constituindo propriamente a mesma unidade de vistas com a Gazeta Polska, contudo, acompanhava a esta nos ataques dirigidos contra o Polak w Brazylii".53

Em 1917, entretanto, ambos os periódicos teriam revisto suas posições e mudado suas perspectivas, focalizando a questão polonesa. Quando o Brasil declarou guerra à Aliança, para aqueles jornais, então, "a colônia polaca, toda

\footnotetext{
${ }^{51}$ Ibidem.

${ }^{52}$ Ibidem, p. 8.

${ }^{53}$ Ibidem.
} 
ela, porquanto nem merece consideração maior uma ou outra opinião isolada, mantinha sempre firme o seu apoio aos aliados". ${ }^{54}$ Ainda assim, para Chmielewski, o Polak era o jornal mais lido, notadamente no Rio Grande do Sul: tendo mais assinantes que os outros e indicando o verdadeiro viés que os colonos poloneses naquele estado representavam e aludiam.

$\mathrm{O}$ autor se impressiona com o posicionamento do clero, pois, todos os padres das colônias por onde passaram e tiveram contato, manifestaram-se em prol dos aliados e contribuíram para os comícios, na recepção dos viajantes e no encontro com os colonos, mesmo quando acusados de serem "germanófilos", ao que o autor conclui

Quanta sinceridade ha nessas demonstrações dos padres, o futuro o provará. o que é certo contudo, o que os seus superiores hierárquicos, os srs. bispos e arcebispos, com a influencia igualmente patriótica dos governos, já os inspiram na orientação melhor a cumprirem não somente o seu dever em relação a Igreja, mas também em relação á Pátria..55

Chmielewski destaca, ainda, que as pré-concepções quanto aos padres, anunciadas em conversas informais, não se confirmavam na prática. Provavelmente estas mudanças de pensamento estivessem ligadas diante do câmbio de posicionamento do Brasil em 1917 e o apoio oficial do estado do Rio Grande do Sul, com a presença de Chmielewski junto à "missão polaca".

Em relação aos voluntários, um dos objetivos centrais de Abczyński, Chmielewski analisava:

Todos os referidos comícios aprovavam por unanimidade sempre a resolução curitibana.

Erguendo vivas ao Brasil, á Polônia, á França e em fim a todos os países aliados, os assistentes já se aprofundavam, em seus pensamentos, no passado, já com, entusiasmo avançavam rapidamente através do futuro. Muitos, comovidos, aproximavam-se do tenente e beijavam o emblema da Polônia - A Águia Branca- que ele trazia no braço esquerdo.

Nos discursos como em palestras não eram empregadas nenhumas palavras que de qualquer maneira pudessem constituir alguma coação moral aos assistentes, a fim de se apresentarem como voluntários do exercito polaco na França.

Entretanto, em cada colônia apresentavam-se imediatamente alguns, prontos a prestarem o compromisso e para dentro de tempo breve seguirem a Porto 'Alegre ou a Coritiba, conforme a respectiva proximidade, afim de lá, na França,

\footnotetext{
${ }^{54}$ Ibidem, p. 5.

${ }^{55}$ Ibidem, p. 29.
} 
nos campos da vida e da morte, representar a Polônia Brasileira, a Polônia Rio-Grandense. ${ }^{56}$

A manifestação de sentimentos de pertença étnica e nacional, o beijo ao símbolo da Águia Branca, ou o comparecimento ao voluntariado, como representação da "Polônia Brasileira" e "Polônia Rio-Grandense", afora o apoio às resoluções e congregação junto aos aliados, davam o tom da configuração identitária dos poloneses. Pelo menos, a partir daquilo que Chmielewski buscava entender como manifestações em prol do que seria uma polonidade' na busca pela volta da independência polonesa, manifestações estas encontradas junto aos colonos nos núcleos visitados pela "missão" e a partir da verificação e descrição de imagens como as da citação acima, permeadas de mobilizações identitárias, emoções e sentimentos voltados à etnicidade ou nacionalismo, bem como nominações de identidade e unidades de pertencimento, das quais aqueles que se voluntariassem, iriam representar na luta pelo retorno da Polônia.

Ao fim da missão polonesa pelo Estado, no ano de 1917, foi então formado um grupo de voluntários que iriam juntar-se às tropas polonesas desenvolvidas na França. Dentre os voluntários, havia professores que atuavam nas escolas étnicas polonesas no Estado, entre outros personagens da colônia polonesa no Rio Grande do Sul.

A constituição de uma nacionalidade em torno da independência da Polônia demarca os processos culturais que proporcionaram os fazeres e as manifestações étnicas no contexto da Primeira Guerra Mundial. No entanto, a Polonidade se apresenta com diferentes aspectos conforme as conotações em que é pensada e produzida pelas lideranças étnicas e suas vinculações políticas (ora mais religiosa ou mais laica e ora ao lado dos poderes centrais ou dos aliados). As manifestações em prol da independência designaram um entendimento incorrendo em diferentes mobilizações na construção de um Estado polonês. Esse processo foi capaz de unir, somente em 1917, diferentes grupos em torno de uma causa comum.

\section{Considerações finais}

No texto do relatório sobre a "Missão Polaca", encaminhado para Borges de Medeiros, Chmielewski analisa, ao final também, o desenvolvimento das colônias polonesas, o qual considera satisfatório, diante da pobreza dos imigrantes oprimidos pelas potências ocupantes na Europa e o quão recente eram

${ }^{56}$ Ibidem, p. 34 . 
esses núcleos coloniais. Faz breves descrições, sobretudo, do crescimento agrícola desenvolvido pelos poloneses no Rio Grande do Sul.

$O$ autor também descreve negativamente os interesses políticos no estado em promover uma nacionalização do ensino, conforme ocorria, desde 1917, no Paraná. Principalmente com a obrigatoriedade do ensino do português em todas as escolas, fator que, naquela altura, não havia sido posto em prática no Rio Grande do Sul, o que considerava positivo.

Em suma, o texto demonstra e permite constatar as múltiplas vinculações, entre os poloneses imigrados, durante a emergência do conflito mundial e a possibilidade de retorno da independência polonesa. Ademais, por ser um relatório para o governador do estado, no qual se buscava demonstrar o engajamento e a adesão dos imigrantes para com os aliados, então apoiados oficialmente pelo Brasil, é também uma propaganda contra os apoiadores dos poderes centrais, em especial, da Alemanha. Explicação dos motivos que teriam levado àquele apoio inicial e um convite para arregimentar voluntários para o exército polonês na França. Dessa forma, estreitaram-se os laços de identidade polonesa entre os imigrantes no Brasil, pois estes agiriam em nome da "Polônia rio-grandense", da "Polônia porto-alegrense", da "Polônia brasileira", em suma, da "colônia polaca", ademais de afirmar a lealdade polonesa para com o Brasil.

Em 1918, após o fim da Primeira Guerra Mundial, a Polônia é reestruturada no cenário político após 123 anos de partilhas, revoluções e tentativas de construção de uma nacionalidade polonesa no contexto europeu. No entanto, o renascimento nacional se dá ao fim, sob a égide do movimento liderado por Pilsudski, até então aliado do lado Austro-húngaro.

Enfim, há uma extrapolação de sentidos heterogêneos que evocam o processo de agregação da nacionalidade polonesa ou a construção de uma polonidade. A independência da Polônia, enquanto nação, vai afetar esse processo, bem como os rumos da produção dos sentidos étnicos da imigração polonesa no Brasil.

No Rio Grande do Sul, um número considerável de imigrantes poloneses viveram o processo de produção e construção de sua etnicidade na interação, ressignificação e configuração de sua cultura, de seus espaços e sentidos da polonidade. O Brasil, por sua vez, estava organizando seu processo de afirmação e construção de uma identidade nacional, com valores advindos da gestação de um nacionalismo, decorrentes de precedentes políticos da Proclamação da República em 1889 e justamente dos acontecimentos que envolveram a I Guerra Mundial. 
Em liberdade de existência, diferentes instituições étnicas continuaram se organizando, construindo e promovendo uma etnicidade polonesa no Rio Grande do Sul de acordo com a heterogeneidade de suas identidades e vinculações políticas de suas lideranças fossem elas adeptas a setores mais conservadores e clericais, ou anticlericais e progressistas, ao longo do período entre guerras.

Artigo recebido para publicação em 13/05/2018 Artigo aprovado para publicação em 06/09/2018 